\title{
Pensononowoor
}

2014, vol. 71, 149-157

http://dx.doi.org/10.12657/denbio.071.015

\author{
Božena Vooková, Andrej Kormuták
}

\section{Study of Abies somatic embryogenesis and its application}

Received: 08 April 2013; Accepted 23 September 2013

\begin{abstract}
This paper provides results of somatic embryogenesis study in our laboratory. General description of somatic embryogenesis (SE) induction, maturation of somatic embryos and plantlets regeneration of the Abies species, followed by a comparisons of some characteristics of zygotic and somatic embryos, seedlings and emblings (somatic seedlings). Own results are supplemented with some literature data. Also aplication of SE for improving of plantlet regeneration of elite fir trees from Dobroč primeval is described as well as initiation of the SE from seeds of incompatible crossings of firs where zygotic embryos abort usually several weeks after pollination.
\end{abstract}

Additional key words: fir, protein analysis, chlorophyll content, macro- and microelements, defence reactions, incompatible crossing

Address: B. Vooková, A. Kormuták, Institute of Plant Genetics and Biotechnology, Slovak Academy of Sciences, Akademická 2, P.O. BOX 39A, 95007 Nitra, Slovak Republic, e-mail: nrgrvook@savba.sk

\section{Introduction}

The discovery of conifer somatic embryogenesis (SE) and the subsequent development of SE protocols for a range of genera and species have opened new research opportunities to forest biotechnologists (Klimaszewska and Cyr 2002). The aim of most tree breeding programmes is to mass produce genetically superior clones or populations. Trees are mostly propaged sexually. Vegetative propagation, however is preferred because superior characteristics are maintained better than by sexual propagation. The most common method of vegetative propagation of conifers has been rooting of cuttings, but current research is not sufficiently developed (Ragonezy et al. 2010). Cuttings often fail to root properly and biggest problem in Abies is prevalent plagiotropic growth of shoots. Rooting problem is associated with tree maturation phase, an age-related developmental process that affects reproductive competence, morphology and growth rate. From this point of view SE is more promising aproach. This system offers the capability to produce unlimited numbers of high-valued plants but it also enables the use of genetic transformation to improve traits such as disease and insect resistance (Kim et al. 2009). SE is interresting for regeneration of Abies species for their tissue genetic stability in condition in vitro (Libiaková et al. 1995; Gajdošová et al. 1995), althoug organic supplement in the medium can affect this stability during long term cultivation (Roth et al. 1997). Also aplication of cryopreservation for embryogenic cells may case a risk for genetic fidelity (Aronen et al. 1999; Krajňáková et al. 2011). 
Abies concerns 40-45 species growing in the Middle and South Europe, in Mediterranean, in East Asia, North Amerika and one species in Quatemala and in Mexico. First notice about initation of SE in Abies is from 1988. In A. alba Mill. embryogenic tissue has been initiated from immature zygotic embryos (Gebhardt et al. 1988). Somatic embryogenesis in Abies with limited success or succesfull regeneration was reported for ten pure species: A. alba Mill., A. balsamea Mill., A. cephalonica Loud., A. cilicica (Antoine et Kotschy) Carrière, A. concolor (Gordon) Lindl. ex Hildebr., A. fraseri (Pursh) Poir, A. koreana Wils., A. nordmanniana LK, A. numidica De Lann. and A. lasiocarpa (Hook.) Nutt. (for review see Vooková and Kormuták 2007). At present, 80 to $90 \%$ of A. nordmanniana embryos with normal morphology can be converted into plantlets, independently of their genotype (Zoglauer et al. 2012).

In our laboratory, besides of pure species also embryogenic cultures of interspecific hybrids have been derived from immature (A. alba $\times$ A. alba, A. alba $\times$ A. nordmanniana, Gajdošová et al. 1995; A. alba $\times$ A. cephalonica, A. alba $\times$ A. numidica, Salajová et al. 1996; A. cilicica $\times A$. nordmanniana, Vooková and Kormuták 2003) and mature (A. alba $\times$ A. cephalonica, Salaj and Salaj 2003/2004) zygotic embryos. In the last time, SE was initiated from immature and mature embryos of $A$. cilicica $\times A$. cephalonica in Czech Republic (Korecký and Vítámvás 2011).

The objective of this report is to present an overview of the Abies somatic embryogenesis research that has been carried out in our laboratory over several years.

\section{Process of somatic embryogenesis in Abies}

Somatic embryogenesis (SE), an asexual way of plant regeneration can be divided into four steps: initiation of embryogenic tissue contained somatic embryos from the primary explant, proliferation of embryogenic tissue (Fig. 1), maturation of somatic embryos (Fig. 2) and regeneration of plants from somatic embryos. Many of the experimental condition of SE can be generalised and used for the most Abies species but it would be optimizing for individual species (Vooková and Kormuták 2004). Developmental stage of zygotic embryo used as explant is important for induction of somatic embryogenesis. In mostly cases, the initiation frequencies of embryogenic tissue were higher when zygotic embryo was in precotyledonary or early cotyledonary stage (Norgaard and Krogstrup 1991; Salajová et al. 1996; Vooková and Kormuták 2003; Kvaalen et al. 2005). Unlike other genera in the Pinaceae, Abies requires only cytokinin for induction of embryogenic tissue from zygotic em-

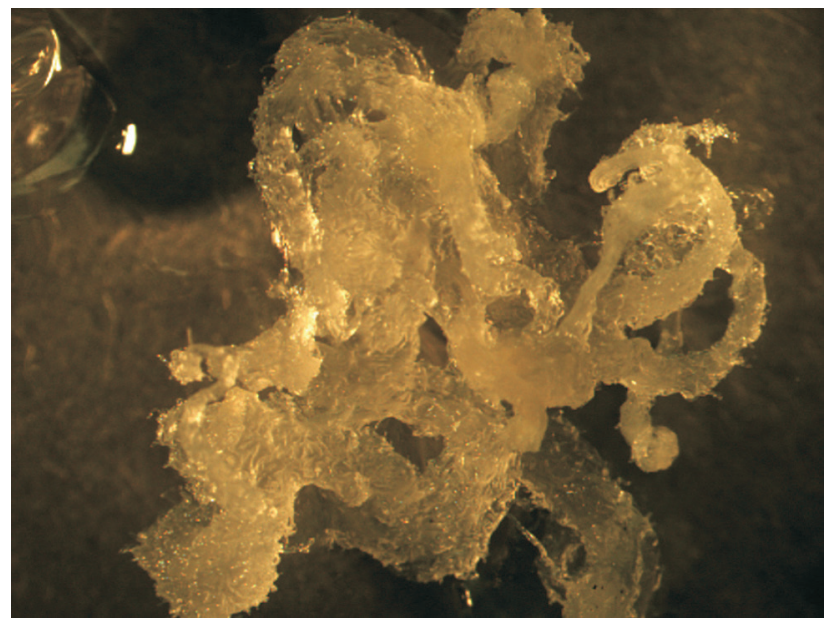

Fig. 1. Proliferation of embryogenic tissue

bryos (Schuller et al. 1989; Nørgaard and Krogstrup 1991), although the embryogenic suspensor mass of A. alba proliferated on a medium supplemented by 2,4-D as well as on an auxin-free medium (Vondráková et al. 2011). To improve maturation process, the most beneficial was pre-culturing of embryogenic tissue on SH medium (Schenk and Hildebrandt 1972) without growth regulator for 2 weeks (Vooková et al. 2010). Maturation of fir somatic embryos is promoted by abscisic acid (ABA) and the presence of carbohydrates in the maturation medium. Maturation medium with $10 \mathrm{mg} \cdot \mathrm{l}^{-1} \mathrm{ABA}$ is the most frequently used for obtaining cotyledonary embryos (Nørgaard 1997; Salajová and Salaj 2003). The production of A. cilici$c a$ and $A$. cilicica $\times A$. nordmanniana mature embryos was influenced by ABA concentration, $20 \mathrm{mg} \cdot \mathrm{l}^{-1}$ was the most effective (Vooková and Kormuták 2003). Maltose gave a better maturation response (Nawrot-Chorabik 2008) and the addition of polyethylene glycol-4000 (PEG) to maturation medium promoted

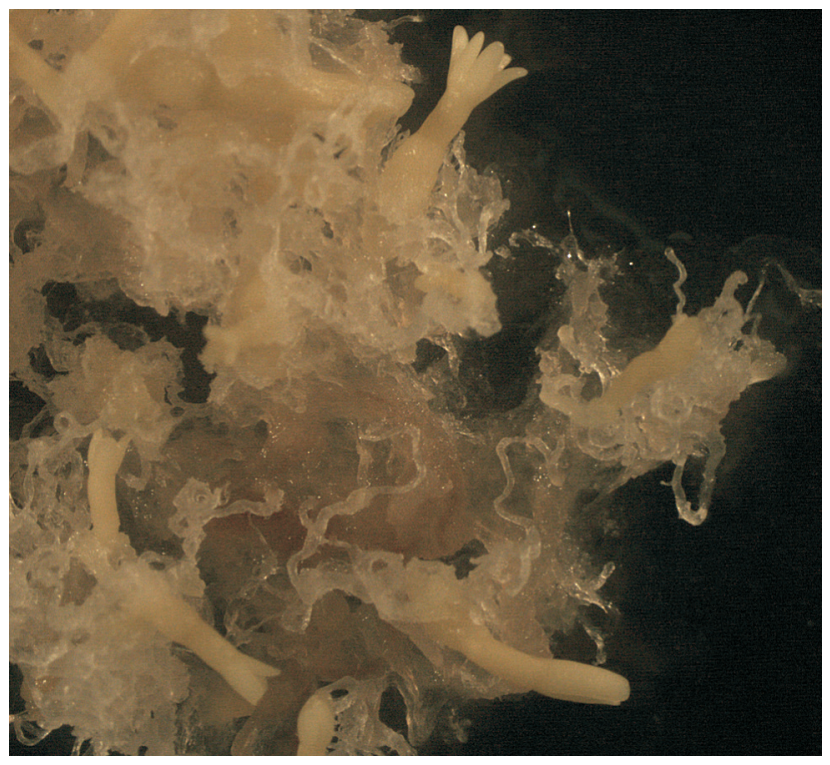

Fig. 2. Somatic embryo maturation 


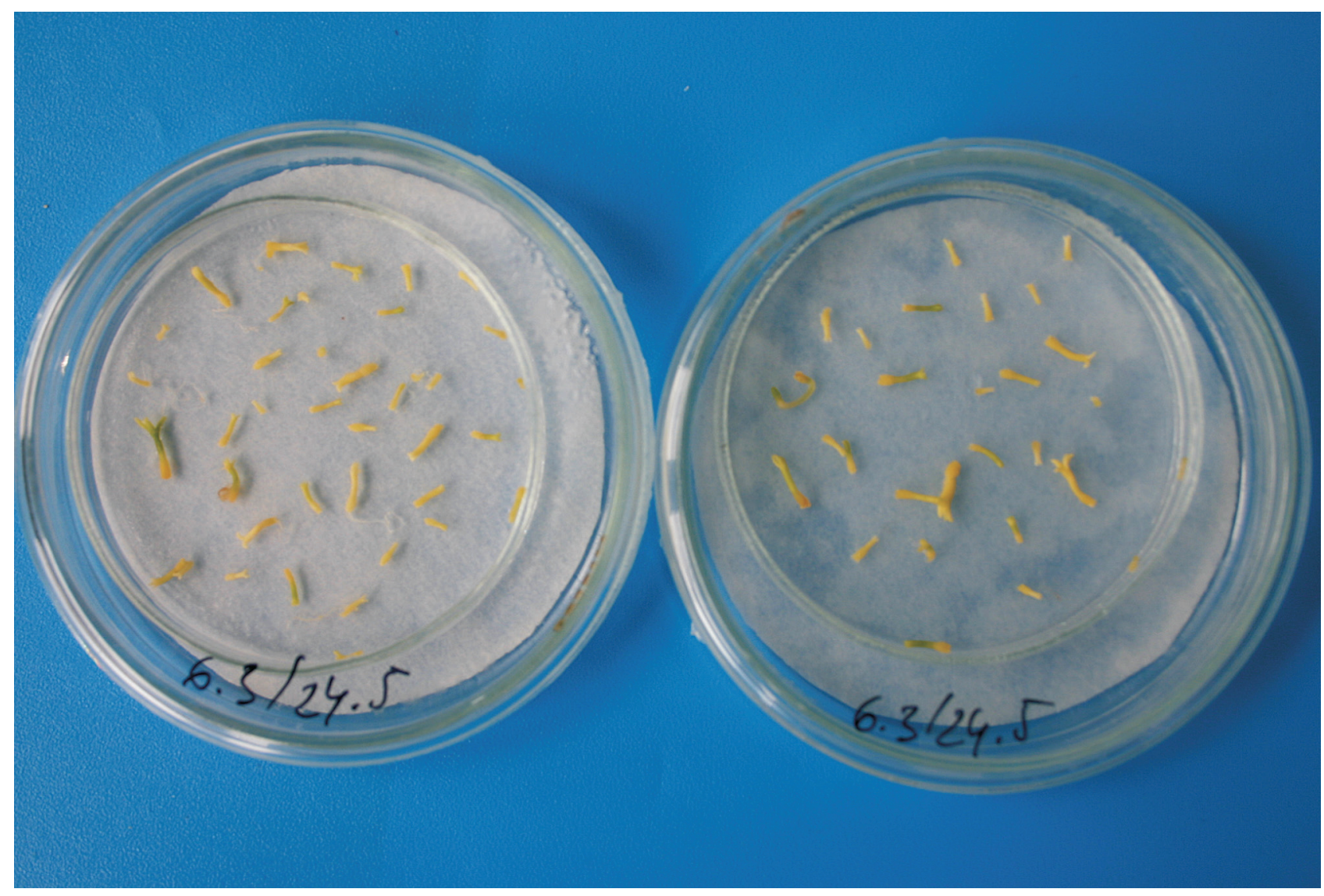

Fig. 3. Desiccation of somatic embryos

the maturation of somatic embryos (Nørgaard 1997; Salajová et al. 2004). Maturation of A. numidica somatic embryos was promoted by $7.5-10 \%$ PEG. Three to $6 \%$ maltose significantly enhanced the yield of mature embryos. The most effective maturation occured when embryogenic tissue was transferred to maturation medium after 14-21 d cultivation on proliferation medium (Vooková and Kormuták 2002). The addition of IBA and PEG into the basal medium with ABA improved A. alba embryo development (Szczygiel and Kowalczyk 2001). Cultivation of A. cephaloni$c a$ embryogenic tissue with the ectomycorrhiza fungi during the proliferation period reduced the proliferation but enhanced the subsequent embryo formation and maturation (Krajňáková et al. 2012).

Variables as a carbon source, ABA and osmotic agents has been used to increase germination and conversion rates of somatic embryos of $A$. cephalonica (Krajňáková et al. 2009). For germination, well-developed cotyledonary somatic embryos used to be selected and subjected to a partial desiccation treatment (Fig. 3) for three weeks (Nørgaard 1997; Vooková et al. 1998; Kvaalen et al. 2005). Media for germination are routinely used with sucrose in $2 \%$ concentration with (Nørgaard 1997) or without activated charcoal (Salajová et al. 1996; Guevin and Kirby 1997). The reduction of sucrose concentration to $1 \%$ had pos-

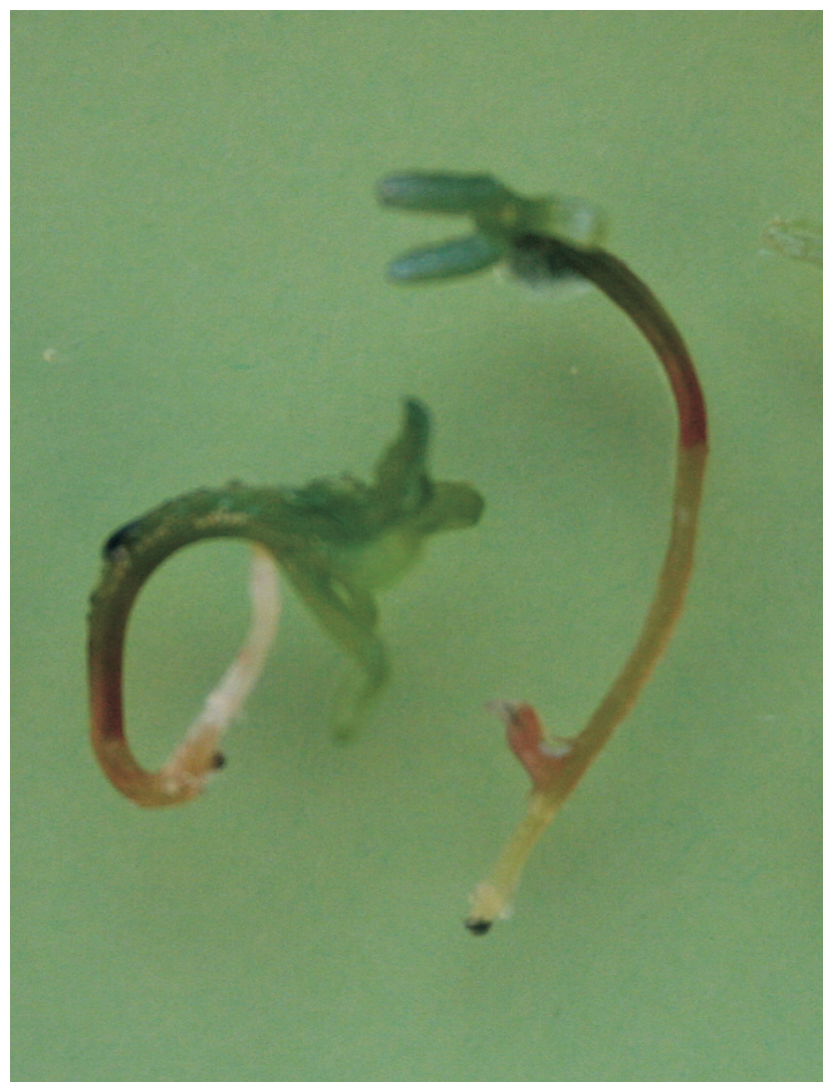

Fig. 4. Germination on half SH medium with $1 \%$ sucrose 
itive influence on A. numidica embryo germination (Vooková and Kormuták 2001).

The high rooting percentage $(85 \%)$ was recorded on half SH medium with $1 \%$ sucrose and $1 \%$ activated charcoal (Fig. 4). It seems that this medium is widely applicable. We used it succesfully for germination of other Abies sp. and hybrids. Somatic seedlings (emblings) regeneration was in our laboratory succesful in: A. numidica, A. cilicica, A. concolor, A. alba, A. cilicica $\times A$. nordmanniana, $A$. nordmanniana $\times A$. veitchii.

The cornerstone of future research will be acclimatisation of somatic seedlings and field establishment of regenerants. A low percentage (less than 5\%) of somatic germinants of $A$. fraseri survived following transplanting to soil however, most of them did not show further growth (Kim et al. 2009). In contrast to other genera, Abies seedlings go into dormancy in the cotyledonary stage even under long-day conditions. However, 2 to 3 months after acclimatisation dormancy can be broken using an artificial cold treatment for 6 weeks minimum at $5^{\circ} \mathrm{C}$ or lower. Although this treatment may speed up their growth, somatic seedlings develop slower and loose up to 1 year compared to plantlets from seeds (Zoglauer et al. 2012).

\section{What differences are between somatic and zygotic embryos?}

Somatic embryos of Abies morphologically resemble zygotic embryos (Fig. 5a, b). They were different in dry mass content, and some differences were found in storage protein synthesis as well as in enzyme activity (Kormuták and Vooková 2001; Kormuták et al. 2003, 2006). Precotyledonary, early cotyledonary and late cotyledonary stages of somatic embryogenesis were characterized by a substantially reduced peroxidase activity compared to callus tissues and regen-


Fig. 5. Somatic (a) and zygotic (b) embryos erated plantlets. In vitro testing of defence reaction showed important differences between somatic and zygotic embryos (Vooková et al. 2012).

\section{Dry mass content of zygotic and somatic embryos}

Dry mass was determined by drying of 50 embryos per treatment at $80^{\circ} \mathrm{C}$ for $48 \mathrm{~h}$. Zygotic embryos contained $66.3 \% \pm 2.54$ of dry mass. Desiccated somatic embryos contained only $23.6 \% \pm 1.28$ of dry mass.

Pullman et. al. (2003) compared Pinus taeda zygotic embryos at different stages of development and most advanced cotyledonary somatic embryos using several measures of embryo quality morphology (dry weight, germination performance, and gene expression). Zygotic embryos showed an increase in dry weight and a decreased percentage of water content as embryo stage advanced. Somatic embryos from genotypes with the most advanced development, resulting decreased dry weight per embryo. Somatic embryo morphology and dry weights were most similar to those of the zygotic embryos at stages 8-9.1. Somatic embryos grow approximately only halfway through the normal sequence of development and then prematurely discontinue growth.

\section{Biochemistry of zygotic and somatic embryos}

The formation of a mature embryo is characterized by the accumulation of LEA and storage proteins. The accumulation of these two types of proteins is controlled by ABA-dependent regulatory mechanisms (Dodeman et al. 1997). Altogether 9 major protein components with molecular masses of 14, 16, 22, $24,27,30,35,38$ and $43 \mathrm{kDa}$ along with numerous minor protein components were detected in zygotic embryos of $A$. alba and $A$. concolor based on soluble protein extraction procedure (Kormuták and Vooková 2000, 2006). However, separated extraction of soluble and insoluble proteins revealed the presence of 4 additional soluble protein components in zygotic embryos of $A$. numidica with molecular masses of 97 , 80,55 and $6 \mathrm{kDa}$ as well as 7 insoluble fractions of 57 , 55, 42, 40, 30, 18 and $14 \mathrm{kDa}$ size (Kormuták et al. 2005). In the light of these findings, a species-specific profile of zygotic embryo proteins may be assumed in Abies. It is worth mentioning that the soluble protein profiles described above differ from those reported for Abies seed by Jensen and Lixue (1991) who were able to distinguish only 4 components in the entire female gametophyte - embryo complex.

As for somatic embryos of $A$. concolor, their soluble protein profiles resemble very closely those of zygotic 
embryos. In contrast, soluble proteins of somatic embryos in A. numidica are similar but not identical with the corresponding profiles of zygotic embryos. In comparison with zygotic embryos the lack of 10, 24 and $34 \mathrm{kDa}$ proteins was registered in mature somatic embryos of the species. Like in zygotic embryos, the $43 \mathrm{kDa}$ protein is the most prominent component of the storage proteins in mature somatic embryos. Its abundance is apparent since the globular stage of somatic embryo formation. All the developmental stages are characterized by an identical protein pattern (Kormuták et al. 2006).

Mature somatic embryos possessed three times higher peroxidase activity than the mature zygotic embryos. The reverse was true of the specific activity of esterase, which was higher in zygotic embryos than in somatic embryos (Kormuták et al. 2003).

A wider picture about quality of somatic embryos we can found in literature data from other authors and species. In Picea glauca, it has been shown that mature somatic embryos have lower amounts of storage proteins and higher starch concentrations than zygotic embryos (Joy et al. 1991), whereas somatic embryos of Pinus strobus have similar or lower amounts of storage protein than zygotic embryos (Klimaszewska et al. 2004). Marked differences were observed in carbohydrate spectra between developing zygotic and maturing somatic embryos of Picea abies (Gösslová et al. 2001). The decrease in total carbohydrate as well as the accumulation of sucrose in later developing stages was a common features in both systems (Konrádová et al. 2002). The concentrations of total lipids exhibited marked variation during maturation of Picea abies somatic embryos, indicating the importance of lipid reserves during embryo development (Svobodová et al. 1999, Grigová et al. 2007). The accumulation of high levels of polyamines in Picea abies somatic embryos may be causally linked to their lower germinability than in zygotic embryos (Gemperlová et al. 2009). Endogenous levels of IAA decreased in the period of embryo development and increased again in the late maturation stage. This pattern was described during development of Pinus sylvestris zygotic embryos (Sanberg et al. 1987) and during early stages of somatic embryogenesis of Picea abies (Vágner et al. 1998).

\section{In vitro defence reactions of somatic and zygotic embryos}

Defence reactions of desiccated cotyledonary somatic embryos and mature zygotic embryos of $A$. numidica were tested in vitro by dual cultures with tester, basidiomycete Phaeolus schweinitzii (Vooková et al. 2012). The growth of mycelium in Petri dish alone and in presence of embryos was measured using a $\mathrm{mm}$ rule and compared. The measurements of fungal mycelium size were taken in 2-day intervals. In presence of somatic and zygotic embryos mycelial growth was inhibited. By this way both types of embryos expressed defence reactions. Greater defence reactions were observed in zygotic embryos relative to defence found in somatic embryos.

\section{Comparisson of some zygotic and somatic seedling (embling) characteristics}

Morfologically there are not differences between zygotic and somatic seedlings (Fig. 6a, b) They were different in dry mass and chlorophylls content as well as in concentration of essential elements. No qualitative differences were detected between the protein profiles of seedlings and emblings.

\section{Accumulation of dry weight in seedlings and emblings}

Accumulation of dry mass in seedlings and emblings during $50 \mathrm{~d}$ of culture was investigated (Table 1). Emblings contained nearly the same percentage of dry mass as seedlings after 14-d cultivation. It is interesting that dry mass of seedlings increased during 50-d of cultivation, while dry mass percentage of emblings was nearly the same during all days of cultivation.

In comparison with emblings, greater shoot and root dry weights of interior spruce sedlings was found also when they grew in soil (Grossnickle and Major 1994). But the emblings of Picea abies and Pseudotsuga menziesii grown in soil for field testing exhibited uniform growth and phenology within a clone, compared with seedlings (Gupta et al. 1996).

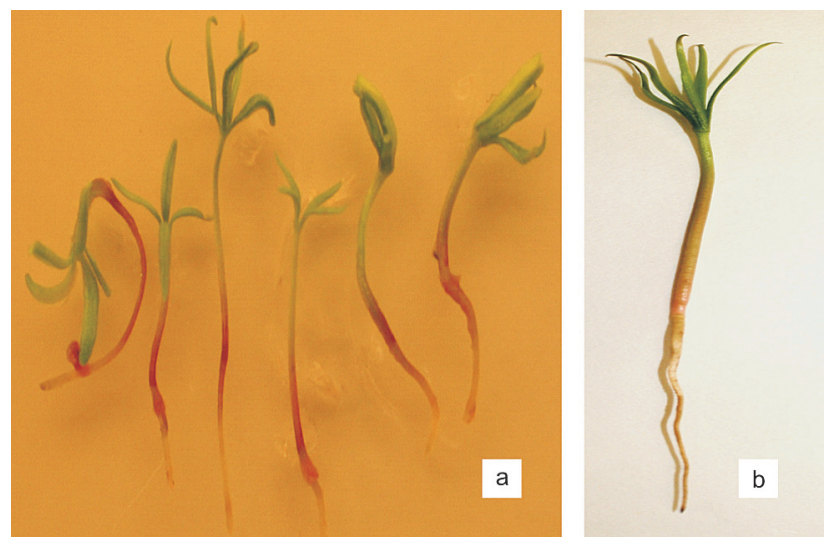

Fig. 6. Somatic (a) and zygotic (b) seedlings 
Table 1. Growth of dry mass (in \%) of seedlings and emblings over 50 days culturing on $1 / 2 \mathrm{SH}$ medium with myo-inositol and IBA. $n=5$. Values followed by the same letters are not significantly different $(\mathrm{p} \leq 0.05)$

\begin{tabular}{lccccc}
\hline \multicolumn{1}{c}{ Material/Days } & 14 & 20 & 30 & 40 & 50 \\
\hline Seedlings & $11.17 \pm 0.67 \mathrm{a}$ & $17.50 \pm 0.72 \mathrm{~b}$ & $18.88 \pm 1.61 \mathrm{~b}$ & $19.71 \pm 0.89 \mathrm{~b}$ & $22.20 \pm 1.12 \mathrm{~b}$ \\
Emblings & $10.03 \pm 0.32 \mathrm{a}$ & $10.51 \pm 1.02 \mathrm{a}$ & $11.48 \pm 0.66 \mathrm{a}$ & $12.34 \pm 0.37 \mathrm{a}$ & $13.44 \pm 0.25 \mathrm{a}$ \\
\hline
\end{tabular}

\section{Chlorophyll content of cotyledons in seedlings and emblings}

This analysis was perform from cotyledon material of 20 days old seedlings and emblings. Content of chlorophyll $a$ and chlorophyll $b$ in seedlings was higher than in emblings (Table 2). But relation of chlorophyll $a$ / chlorophyll $b$ was $2 / 1$. This relation was usualy found also in cotyledons of some conifer species seedlings and leaves of higher plants (Šalgovičová and Hudák 2005).

Table 2. Chlorophyll content in mg per g of dry weight in cotyledons of 20 days seedlings and emblings. Means $\pm \mathrm{SE}, \mathrm{n}=6$; Values followed by the same letters are not significantly different $(\mathrm{p} \leq 0.05)$

\begin{tabular}{cccc}
\hline Material & Chlorophyll $a$ & Chlorophyll $b$ & Relation $a / b$ \\
\hline Seedlings & $0.6156 \pm 0.05 \mathrm{a}$ & $0.2882 \pm 0.07 \mathrm{c}$ & 2.13 \\
Emblings & $0.2700 \pm 0.04 \mathrm{~b}$ & $0.1033 \pm 0.02 \mathrm{~d}$ & 2.61 \\
\hline
\end{tabular}

\section{Concentrations of essential elements in seedlings and emblings}

The content of macro- and microelements differed between seedlings and emblings. Higher micronutrients contents were found in seedlings, also Fe contents was higher in seedlings. All these results indicate higher physiological activity of seedlings. But C and $\mathrm{N}$ contents were higher in emblings as well as concentrations of $\mathrm{K}, \mathrm{Ca}, \mathrm{Mg}$ and $\mathrm{Na}$.

\section{Protein analysis of seedlings and emblings}

No qualitative differences were detected between the protein profiles of seedlings and emblings. In both cases the electroforetic patterns consisted of 11 protein bands of comparable molecular size with major proteins positioned at $55.6 \mathrm{kDa}$ and $26.6 \mathrm{kDa}$. The protein fraction of $43 \mathrm{kDa}$ size which is considered to be the major storage protein in Abies (Jensen and Lixue 1991) was less abundant as contrasted with abundancy of $26 \mathrm{kDa}$ protein which is another storage protein specific for Abies. It is obvious that with respect to these characteristics seedlings and emblings share the same quality. In comparison with other developmental stages of somatic embryos, a no- ticeable increase of the $55 \mathrm{kDa}$ protein was observed in regenerated emblings (Kormuták et al. 2006).

\section{Utilize of the methods of somatic embryogenesis}

Applications of this process include: clonal propagation of genetically uniform plant material, elimination of viruses, can be used in the regeneration of genetically transformed plants, provision of source tissue for genetic transformation, development of synthetic seed technology, metabolite production, also offers unique opportunities as a model system for learning to study embryology.

Our results confirm, that methods of SE process can be used for regeneration of elite fir individuals from primeval (Vooková and Kormuták 2009). With more or less succes it is possible to obtained fir hybrids from in nature incompatible crossing, where zygotic embryos abort usually several weeks after pollination (Vooková and Kormuták 2008).

\section{Improved plantlet regeneration of Abies alba trees of Dobroč primeval}

Somatic embryogenesis was initiated from immature zygotic embryos of Abies alba Mill. from open-pollinated families of 4 trees in Dobroč primeval. Totally, two from the primeval families (50\%) responded to initiation condition. Initiation frequencies among families ranged in primeval 5.4-16.8\%. Maturation ability was shown by $77.3 \%$ of the primeval cell lines. Mature cotyledonary embryos were converted into emblings. Regenerants were obtained from 9 cell lines of two Dobroč primeval families (trees).

In summary, SE seems to be convenient supplementary tool for in vitro conservation of primeval forest genetic resources and/or for preservation of elite trees of silver fir by micropropagation. The results of this study indicate that embryogenic potential of immature zygotic embryos is independent on stands but dependent on genotype. Also biochemically, no differences were found between somatic embryos derived from zygotic embryos of silver fir primeval stand and somatic embryos originating from the trees of managed stand. 


\section{Somatic embryogenesis in some hybrid firs from artifficial pollination}

Methods of SE process can be used for recovering plants from sexual crosses where the majority of embryos cannot survive in vivo. It would be also applied more or less successfully for raising hybrids from a number of incompatible crosses. Embryo rescue has been carried out with a large number of species inluding tree species, but to our knowledge has never been ettempted to conifer.

The present study was aimed at initiation of the somatic embryogenesis from immature seeds of incompatible crossings of fir species: $A$. concolor $\times$ A.weitchii, A. concolor $\times A$. alba, A. concolor $\times A$. pinsapo, A.nordmanniana $\times$ A. veitchii, A.nordmanniana $\times$ A. concolor, A. pinsapo $\times A$. veitchii, $A$. pinsapo $\times A$. concolor, A. alba $\times A$. veitchii. The number of explants available at the date of collection was limited by the number of developing megagametophytes in a cone. Later when embryo was not present any more in developing seeds and megagametophytes degenerated meanwhile, the seeds were too hard to remove their coats. The induction of embryogenic tissue was rather rare and occurred with frequencies of $0.64-1.6 \%$ in $A$. nordmanniana $\times A$. concolor, $0.69-3.82 \%$ in $A$. nordmanniana $\times A$. veitchii, $5.55 \%$ in $A$. concolor $\times A$. veitchii, $0.64-1.60 \%$ in $A$. nordmanniana $\times$ A. concolor and $1.23 \%$ in $A$. pinsapo $\times A$. veitchii.

Maturation and development of cotyledonary stage somatic embryos was achieved only in $A$. nordmanniana $\times A$. veitchii. Ten cell lines response to maturation treatment. Maturation was observed also in two cell lines of $A$. concolor $\times A$. veitchii but they formed only globule-shaped embryos. These cell lines represented group B with undeveloped somatic embryos (Mo et al. 1996; Salajová and Salaj 2005). After partial desiccation the mature embryos of $A$. nordmanniana $\times A$. veitchii germinated to small plantlets. But not every line embryos respond to the germination treatment. This step was succesful in six cell lines.

Molecular evidence for the hybrid nature of $A$. nordmanniana $\times A$. veitchii cross was based on the paternal inheritance of cpDNA. The presence of 550 bp restriction fragment of $A$. veitchii paternal tree in all the 10 cell lines with maturation response may be considered as evidence supporting their hybridity. But it was not possible to prove the hybrid nature of $A$. concolor $\times A$. veitchii cell line. This cell line was of $A$. concolor instead of $A$. veitchii haplotype.

The results of this study indicated that biotechnology is now at a stage when its application in hybridological studies is becoming a reality opening a new perspective for obtaining exceptional hybridological material not only in horticulture but also in forestry.

\section{Acknowledgements}

This study was financially supported by the VEGA Grant Agency, Project No. 2/0057/13.

\section{References}

Aronen T.S., Krajňáková J., Haggman H.M., Ryynanen L.A. 1999. Genetic fidelity of cryopreserved embryogenic cultures of open-pollinated Abies cephalonica. Plant Science 142: 163-172.

Dodeman V.L., Ducreux G., Kreis, M. 1997. Review article. Zygotic embryogenesis versus somatic embryogenesis. Journal of Experimental Botany 48: 1493-1509.

Gajdošová A., Vooková B., Kormuták A., Libiaková G., Doležel J. 1995. Induction, protein composition and DNA ploidy level of embryogenic calli of silver fir and its hybrids. Biologia Plantarum 37: 169-176.

Gebhardt K.H., Weisberger H., Fröhlich H.J. 1988. In vitro germination and production of embryogenic callus from liquid suspension cultures of Abies alba. International Conifer Tissue Culture Working Group, poster no. 17, Saskatoon, Canada.

Gemperlová L., Fischerová L., Cvikrová M., Mala J., Vondráková Z., Martincová O., Vágner M. 2009. Polyamine profiles and biosynthesis in somatic embryo development and comparison of germinating somatic and zygotic embryos of Norway spruce. Tree Physiology 29: 1287-1298.

Gösslová M., Svobodová H., Lipavská H., Albrechtová J., Vreugdenhil D. 2001. Comparing carbohydrate status during Norway spruce seed development and somatic embryo formation. In Vitro Cellular and Developmental Biology-Plant 37: 24-28.

Grigová M., Kubeš M., Drážná N., Řezanka T., Lipavská H. 2007. Storage lipid dynamics in somatic embryos of Norway spruce (Picea abies): histochemical and quantitative analyses. Tree Physiology 27: 1533-1540.

Grossnickle S.C., Major J.E. 1994. Interior spruce seedlings compared with emblings produced from somatic embryognesis. II. Stock quality assessment prior to field planting. Canadian Journal of Forest Research 24: 1385-1396.

Guevin T.G., Kirby E.G. 1997. Induction of embryogenesis in cultured mature zygotic embryos of Abies fraseri (Pursh) Poir. Plant Cell Tissue Organ Culture 49: 219-222.

Gupta P.K., Timmis R., Timmis K.A., Grob J.A., Carlson W.C., Welty D.E. 1996. Clonal propagation of conifers via somatic embryogenesis. Forestry Sciences 49: 3-9.

Jensen U., Lixue C. 1991. Abies seed protein profile divergent from other Pinaceae. Taxon 40: 435-440. 
Joy. R.W. IV, Yeung E.C., Kong L., Thorpe T.A. 1991. Development of white spruce somatic embryos: I. Storage product deposition. In Vitro Cellular and Developmental Biology-Plant 27: 32-41.

Kim Y.W., Newton R., Frampton J., Han K.-H. 2009. Embryogenic tissue initiation and somatic embryogenesis in Fraser fir (Abies fraseir [Pursh] Poir.). In Vitro Cellular and Developmental Biology-Plant 45: 400-406.

Klimaszewska K., Cyr D.R. 2002. Conifer somatic embryogenesis: I. Development. Dendrobiology 48: 31-39.

Klimaszewska K., Morency F., Jones-Overton C., Cooke J. 2004. Accumulation pattern and identification of seed storage proteins in zygotic embryos of Pinus strobus and in somatic embryos from different maturation treatments. Physiologia Plantarum 121: 682-690.

Konrádová H., Lipavská H., Albrechtová J., Vreugdenhil D. 2002. Sucrose metabolism during somatic and zygotic embryogeneses in Norway spruce: content of soluble saccharides and localisation of key enzyme activities. Journal of Plant Physiology 159: 387-396.

Korecký J., Vítamvás, J. 2011. Somatic embryogenesis of the hybrid Abies cilicica $\times$ Abies cephalonica. Journal of Forest Science 57: 401-408.

Kormuták A., Vooková B. 2000. Soluble proteins during silver fir (Abies alba Mill.) embryogeny. In: Cytogenetic Studies of Forest Trees and Shrubs-Review, Present Status, and Outlook on the Future. Guttenberger H., Borzan Ž., Schlarbaum S.E., Hartman T.P.V. (eds). Arbora Publishers, Zvolen, Slovakia, pp 95-102.

Kormuták A., Vooková B., 2001. Peroxidase activity in non-embryogenic and embryogenic calli and in developing somatic embryos of white fir (Abies concolor Gord. et Glend). Plant Biosystems 135: 101-105.

Kormuták A., Salaj T., Matúšová R., Vooková B. 2003: Biochemistry of zygotic and somatic embryogenesis in silver fir (Abies alba Mill.) Acta Biologica Cracoviensia Series Botanica 45: 59-62.

Kormuták A., Salaj J., Vooková B. 2005. Storage proteins and enzyme activity in somatic and zygotic embryos of Algerian fir (Abies numidica De Lann.). In: From Laboratory to Business $-6^{\text {th }}$ International Symposium in the Series Recent Advances in Plant Biotechnology, Book of Abstracts, September 1216, 2005, České Budějovice. Břiza J., Pavingerova D., Špak J. (eds). Czech Republic, Attavena Publisher, České Budějovice, Czech Republic, pp 104.

Kormuták A., Salaj J., Vooková B. 2006. Storage protein dynamics in zygotic and somatic embryos of white fir. Biológia 61: 479-485.

Krajňáková J., Haggman H., Gomory D. 2009. Effect of sucrose concentration, polyethylene glycol and activated charcoal on maturation and regeneration of Abies cephalonica somatic embryos. Plant Cell Tissue and Organ Culture 96: 251-262.

Krajňáková J., Sutela S., Aronen T., Gomory D., Vianello A., Haggman H. 2011. Long-term cryopreservation of Greek fir embryogenic cell lines: Recovery, maturation and genetic fidelity. Cryobiology 63: 17-25.

Krajňáková J., Niemi K., Gomory D., Haggman H. 2012. Effects of different ectomycorrhizal fungi on somatic embryogenesis of Abies cephalonica Loud. In Plant Cell Tissue and Organ Culture 109: 353-361.

Kvaalen H., Daehlen O.G., Rognstad A.T., Grønstad B. 2005. Somatic embryogenesis for plant production of Abies lasiocarpa. Canadian Journal of Forest Research 35: 1053-1060.

Libiaková G., Gajdošová A., Vooková B., Kubincová M., Doležel J. 1995. Karyological study of Abies concolor $\times$ Abies grandis calli and shoots regenerated in vitro. Biologia 50: 61-64.

Nawrot-Chorabik K. 2008. Embryogenic callus induction and differentiation in silver fir (Abies alba Mill.) tissue cultures. Dendrobiology 59: 31-40.

Mo L. H., Egertsdotter U., vonArnold S. 1996. Secretion of specific extracellular proteins by somatic embryos of Picea abies is depended on embryo morphology. Annals of Botany 77: 143-152.

Nørgaard J.V., Krogstrup P. 1991. Cytokinin induced somatic embryogenesis from immature embryos of Abies nordmanniana LK. Plant Cell Reports 9: 509-513.

Nørgaard J.V. 1997. Somatic embryo maturation and plant regeneration in Abies nordmanniana LK. Plant Science 124: 211-221.

Pullman G.S, Johnson S., Peter G., Cairney J., Xu N. 2003. Improving loblolly pine somatic embryo maturation: comparison of somatic and zygotic embryo morphology, germination, and gene expression. Plant Cell Report 21: 747-758.

Ragonezi C., Klimaszewska K., Castro M.R., Lima M., De Oliviera P., Zavattieri M.A. 2010. Adventitious rooting of conifers: influence of physical and chemical factors. Trees 24: 975-992.

Roth R., Ebert I., Schmidt J. 1997. Trisomy associated with loss of maturation capacity in a long-term embryogenic culture of Abies alba. Theoretical and Applied Genetics 95: 353-358.

Salajová T., Salaj J., Jásik J., Kormuták A., Hakman I. 1996. Embryogenic culture initiation and somatic embryo development in hybrid firs (Abies alba $\times$ Abies cephalonica and Abies alba $\times$ Abies numidica). Plant Cell Report 15: 527-530.

Salajová T., Salaj J. 2003. Somatic embryo formation on mature Abies alba $\times$ Abies cephalonica zygotic embryo explants. Biologia Plantarum 47: 7-11.

Salajová T., Matúšová R., Salaj J. 2004. The effect of carbohydrates and polyethylene glycol on somatic 
embryo maturation in hybrid fir Abies alba $\times$ Abies numidica. Acta Biologica Cracoviensia, Series Botanica 46: 159-167.

Salajová T., Salaj J. 2005. Somatic embryogenesis in Pinus nigra: embryogenic tissue initiation, maturation and regeneration ability of established cell lines. Biologia Plantarum 49: 333-339.

Sandberg G., Ernstsen A., Hamnede M. 1987. Dynamics of indole-3-acetic acid and indole-3-ethanol during development and germination of Pinus sylvestris seeds. Physiologia Plantarum 71: 411-418.

Schenk R.U., Hildebrandt A.C. 1972. Medium and techniques for induction and growth of monocotyledonous plant cell cultures. Canadian Journal of Botany 50: 199-204.

Schuller A., Reuther G., Geier T. 1989. Somatic embryogenesis from seed explants of Abies alba. Plant Cell Tissue and Organ Culture 17: 53-58.

Svobodová H., Albrechtová J., Kumštýřrová L., Lipavská H., Vágner M., Vondráková Z. 1999. Somatic embryogenesis in Norway spruce: Anatomical study of embryo development and influence of polyethylene glycol on maturation process. Plant Physiology and Biochemistry 37: 209-221.

Szczygieł K., Kowalczyk J. 2001. Somatic embryogenesis of silver fir (Abies alba Mill.) - polish provenances. Proceedings of the Fourth International Symposium In Vitro Culture and Horticultural Breeding. Tampere, Finland. Acta Horticulture 560: 509-512.

Šalgovičová I., Hudák J. 2005. Photosynthetic apparatus in the seedlings of scots pine and mountain. In: Plant Physiology Conference of PhD Students and Young Scientists. BI SAS, PFUK, Bratislava, p. 37.

Vágner M., Vondráková Z., Strnadová Z., Eder J., Macháčková I. 1998. Endogenous levels of plant growth hormones during early stages of somatic embryogenesis of Picea abies. Advances in Horticultural Science 12: 11-18.

Vondráková Z., Eliášová K., Fischerová L., Vágner M. 2011. The role of auxins in somatic embryogenesis of Abies alba. Central European Journal of Biology 6: 587-596.

Vooková B., Gajdošová A., Matúšová R. 1998. Somatic embryogenesis in Abies alba $\times$ Abies alba and
Abies alba $\times$ Abies nordmanniana hybrids. Biologia Plantarum 40: 523-530.

Vooková B., Hříb J., Adamec V. 2012. Testing of Algerian fir zygotic and somatic embryos on defence reactions in vitro. Plant Soil and Environment 58: 84-90.

Vooková B., Kormuták A. 2001. Effect of sucrose concentration, charcoal, and indole-3-butyric acid on germination of Abies numidica somatic embryos. Biologia Plantarum 44: 181-184.

Vooková B., Kormuták A. 2002. Some features of somatic embryo maturation of Algerian fir. In Vitro Cellular and Developmental Biology-Plant 38: 549-551.

Vooková B., Kormuták A. 2003. Plantlet regeneration in Abies cilicica and Abies cilicica $\times$ Abies nordmanniana hybrid via somatic embryogenesis. Turkish Journal of Botany 27: 71-76.

Vooková B., Kormuták A. 2004. Propagation of some Abies species by somatic embryogenesis. Acta Universitatis Latviensis, Biology 676: 257-260.

Vooková B., Kormuták A. 2007. Abies Biotechnology - Research and Development of Tissue Culture Techniques for Vegetative Propagation. Tree and Forestry Science and Biotechnology 1: 39-46.

Vooková B., Kormuták A. 2008. Somatic embryogenesis in immature zygotic embryos of firs from incompatible crossings. Propagation of Ornamental Plants 8: 33-35.

Vooková B., Kormuták A. 2009. Improved plantlet regeneration from open-pollinated families of Abies alba trees of Dobroč primeval forest and adjoing managed stand via somatic embryogenesis. Biologia 64: 1136-1140.

Vooková B., Machava J., Šalgovičová A., Kormuták A. 2010. Optimization of Algerian fir somatic embryos maturation. Biologia Plantarum 54: 177-180.

Zoglauer K., Aurich C., Uehre P., Herrmann S. 2012. Somatic embryogenesis in Abies nordmanniana: present status and future application In: Integrating vegetative propagation, biotechnologies and genetic improvement for tree production and sustainable forest management. Park Y.S., Bonga J.M. (eds). Proceedings of the IUFRO Working Party 2.09.02 conference. Brno Czech Republic, p. 196. 